\title{
WHAT MAKES WILDLIFE TOURISTS HAPPY AND WHAT DISAPPOINTS THEM? LEARNING FROM REVIEWS POSTED ON TRIPADVISOR
}

\author{
István EGRESI* \\ 1. Department for Management of Science and Technology \\ Development, Ton DucThang University, Ho Chi Minh City, Vietnam; \\ 2. Faculty of Environment and Labour Safety, \\ Ton DucThang University, Ho Chi Minh City, Vietnam, e-mail: istvan.egresi@tdt.edu.vn
}

\author{
Thambiliya Godage Supun Lahiru PRAKASH \\ 1. Department of Forestry and Environmental Science, \\ University of Sri Jayewardenepura, Nugegoda, Sri Lanka; \\ 2. Biodiversity Conservation and Research Circle of Sri Lanka, \\ No 50/1, Paranakanda, Wattala, Sri Lanka, e-mail: prakashtgsl@gmail.com
}

\begin{abstract}
Citation: Egresi, I., \& Prakash, T.G.S.L. (2019). WHAT MAKES WILDLIFE TOURISTS HAPPY AND WHAT DISAPPOINTS THEM? LEARNING FROM REVIEWS POSTED ON TRIPADVISOR. GeoJournal of Tourism and Geosites, 24(1), 102-117. https://doi.org/10.30892/gtg.24109-346
\end{abstract}

\begin{abstract}
Wildlife tourism is one of the fastest growing tourism sectors worldwide and has been increasingly used to promote tourism in certain countries. With 26 national parks and 61 wildlife reserves covering $13 \%$ of its land surface area, Sri Lanka has a great potential to become one of the world's hotspots for wildlife tourism. However, in order to ensure a sustainable development of this sector it is essential to evaluate tourists' level of satisfaction with their experience. This research examined the main factors contributing to tourist satisfaction / dissatisfaction in Sri Lanka's most visited national park. QDA Miner and Wordstat software were used for the qualitative content analysis and coding of reviews posted by international tourists on TripAdvisor. The research revealed that the great majority of visitors were satisfied with their visit at Yala National Park. However, this overall assessment masks a highly uneven visitor experience which was understood only after qualitatively analyzing the content of the visitors' comments. The study found that satisfaction/dissatisfaction of visitors depends on three main factors: the number and diversity of animals, the number of vehicles and tourists and the knowledge and skills of guides and drivers. These findings have a number of managerial implications which are highlighted at the end of the study.
\end{abstract}

Key words: wildlife tourism, safari tourism, tourist satisfaction, user-generated content (UGC), TripAdvisor, Sri Lanka

*Corresponding author 


\section{INTRODUCTION}

One of the fastest growing tourism sectors worldwide (Rodger et al., 2007), wildlife tourism is an important source of money and a major component of the host country economy (Higginbottom, 2004), especially in Southern and Eastern Africa (Akama et al., 2011; Akama and Kieti, 2003; Brooks et al., 2011; Mbaiwa, 2011; Okello et al., 2008; 2005). For example, wildlife tourism accounts for $70 \%$ of total tourism earnings in Kenya, $25 \%$ of the GDP and more than 10\% of total formal employment (Akama et al, 2011, citing governmental documents). While not nearly as important as in Africa, wildlife tourism is also gaining importance in some Asian countries such as Thailand (Duffy and Moore, 2010) and China (Cong et al., 2014) and is developing very fast in Sri Lanka, a developing country of over 22 million people situated southeast of the Indian Peninsula. Sri Lanka's economy was hampered for 26 years by a civil war between the government and the Liberation Tigers of Tamil Eelam (LTTE) and desperately needs to increase tourism income in order to recover. Sri Lanka is a country with great potential for the development of wildlife tourism. The country boasts numerous national parks and reserves that could be used by marketers to attract international tourists. Together with the Western Ghats, Sri Lanka is one of the world biodiversity hotspots (Mittermeier et al., 1999) and has the highest density of flowering plant, amphibian, reptile and mammal species in Asia (Weerakoon, 2012 citing a document released by the government). There are 26 national parks in Sri Lanka covering an area of $5734 \mathrm{~km}^{2}$ and 61 wildlife sanctuaries with a total area of $2780 \mathrm{~km}^{2} .^{1}$ In total, over $8500 \mathrm{~km}^{2}$ or $13 \%$ of Sri Lanka's land surface area has been designated as Wildlife Protected Areas (WLPAs).

Designated as a life sanctuary in 1900 and declared a national park in 1938, Yala is the most visited national park in Sri Lanka (Buultjens et al., 2005). Situated in the southeast of the country and covering 97,881 hectares (International Water Management Institute, 2006), it is home to 215 species of birds - of which seven are endemic to Sri Lanka - and 44 species of mammals (Senaratna, 2009). Among these, sloth bears and elephants are major attractions for tourists. However, what makes Yala unique among the natural parks in Sri Lanka is its leopard population - the park is home to one of the highest densities of leopard in the world (Kittle, 2009). There is a strong support for further tourism development among the local communities so there are plans to increase visitation levels (Chandralal et al., 2010). However, this massive increase in the number of visitors, especially to national parks and other protected areas already poses a major challenge to nature conservation as well as to the experience of the visitors (Rathnayake, 2016b).

In order to ensure a sustainable development of this sector it is essential to evaluate tourists' level of satisfaction with their experience. Satisfaction of visitors plays an important role in planning and marketing wildlife tourism products and destinations (Yoon and Uysal, 2005) and in increasing destination competitiveness (Andriotis et al., 2008). It has been reckoned that tourist satisfaction leads to repeat visits and/or positive word-of-mouth (Som \& Badarneh, 2011) as well as improved brand equity and increased revenues for destinations as tourists will be willing to pay more for their experience (Dmitrovic et al., 2009). Any form of feedback from tourists could help destination developers and marketers to identify the main issues regarding visitor satisfaction and help design tools to improve the image of the destination and increase satisfaction (Andriotis et al., 2008; Egresi and Polat, 2016). Analyzing the factors that influence visitor satisfaction with their experience is of paramount importance, especially in wildlife tourism where tourism development needs to happen in parallel with biodiversity conservation and local community development (Torres-Sovero et al.,

\footnotetext{
${ }^{1}$ According to Sri Lanka's Department of Wildlife Conservation (www.dwc.gov.lk).
} 
2012). Understanding the interaction between tourists and wildlife is, also, important for the sustainability of the industry (Rodger et al., 2007).

In general, visitor satisfaction has been investigated with the use of quantitative methods. However, the use of questionnaires and Likert scale questions to examine tourists' satisfaction is not always the research method that leads to the most accurate results (Alegre and Garau, 2010); some researchers have noted that these questionnaires are biased towards more positive ratings of the destination attributes (Oh et al., 2001). More recently, qualitative methods, such as content analysis of reviews posted by users on travel sites started to be employed; however, their use is still limited. To the best knowledge of the authors there are only a few studies on wildlife tourism based on content analysis of reviews posted on specialized sites such as TripAdvisor and even fewer dealing with visitors' satisfaction. Aiming at filling in this gap, this study will attempt to answer the following questions:

1. Whether or not international tourists visiting national parks in Sri Lanka are satisfied with their overall experience.

2. What are the most important factors that could determine international tourists' satisfaction with their experience visiting these parks?

\section{LITERATURE REVIEW \\ Wildlife tourism}

Wildlife tourism is a form of alternative tourism (Egresi, 2016) that is undertaken to view and/or encounter wildlife (Newsome et al., 2004). It includes a diversity of activities such as bird watching, wildlife observing, photo safari, whale watching, trophy hunting, sport fishing, and reef diving (Rathnayake, 2016a). Wildlife tourism could be about animals in captive or semi-captive state or about animals roaming freely in the wild (Newsome et al., 2004). In the first case it could include more interactive activities, such as feeding and/or touching the animals while in the latter case tourists' activities are limited to observing and photographing (non-consumptive activities) or hunting and fishing (consumptive activities) (Higginbottom, 2004; Newsome et al., 2004). In this study, by wildlife tourism, we understand only those activities undertaken by tourists to observe and photograph wild animals in their natural, non-enclosed environment.

Worldwide, the number of tourists interested in wildlife is constantly rising. It is estimated that between $20 \%$ and $40 \%$ of international tourists could be engaged in wildlife tourism (Rathnayake, 2016a). Wilderness tourism usually takes place in state-run protected areas but sometimes could be organized on privately-owned and operated wildlife "farms" where wilderness has been commodified (Brooks et al., 2011). In some destinations, wildlife tourism is the sole attraction while in others it is promoted in tandem with other tourism forms and products such as nature-based tourism, rural tourism, cultural tourism or religious tourism (Valentine and Birtles, 2004). In general, tourists have a preference for dangerous animals - both herbivores and predators (Newsome et al., 2004) and for wildlife that is endangered, threatened or rare (Cong et al., 2004; Higginbottom, 2004). Ideally, animals and birds favored by tourists should be active during the day and easy to approach and observe, tolerate visitors easily and exist in great number and/or display great varieties (Reynolds \& Braithwaite, 2001).

Besides economically benefiting local communities (Mbaiwa, 2011), development of wildlife tourism could also finance the conservation and preservation of biodiversity and local ecosystems (Tisdell and Wilson, 2001). Moreover, wildlife tourism also includes an educational component; if properly done, it can educate visitors to become more aware of the needs for biodiversity conservation and to behave in a way that would minimize harm to the wildlife (Ballantyne et al., 2011). The main challenge for the providers of wildlife 
tourism products and services is to provide tourists with the best experience, while, at the same time minimizing their impact on the environment (Reynolds \& Braithwaite, 2001).

\section{Tourist satisfaction}

Satisfaction is a multifaceted concept that measures to what degree tourists' expectations are fulfilled by their experience at the destination (Pizam et al., 1978). Satisfaction has been approached from different angles and a number of theories have been developed to explain it. One of the most popular theories among scholars of tourism studies is the disconfirmation theory (Oliver, 1980). This theory states that tourists have previous expectations and satisfaction with their experience results from comparing these expectations with the perceived experience visiting the destination (Pizam \& Milan, 1993). If the experience is better than or matches the expectations (positive disconfirmation), then we can say that the visitor is highly satisfied and looks forward to returning in the future (Akama \& Kieti, 2003; Yu \& Goulden, 2006). If the experience is not up to its expectations (negative disconfirmation), the visitor is dissatisfied and is unlikely to return and/or recommend the destination to others (Yoon \& Uysal, 2005).

However, not always tourist satisfaction leads to increased number of tourists (Akama \& Kieti, 2003).Overall satisfaction does not guarantee repeat visitation as often tourists prefer not to visit a place twice and, instead, to look for new destinations ( $\mathrm{Yu}$ and Goulden, 2006). However, they can still promote the destination in case of positive experiences by recommending it to others (Akama \& Kieti, 2003; Lee et al., 2007; Yu and Goulden, 2006). Assessment of visitor satisfaction is very complex and includes also experiences of tourists with services and facilities at the destination as well as personal interaction experiences, including the performance of the tour guide/driver (Chen et al. 2011; Reynolds \& Braithwaite, 2001). Moreover, tourist satisfaction depends not only on the quality of the tourism product and/or service but also on price and the perceived value of the product and/or service (Akama \& Kieti, 2003; Lee et al., 2007).

\section{Use of reviews posted on TripAdvisor for data collection}

Word of mouth is a cheap and very powerful strategy to attract tourists to a destination (Okello et al., 2005) and plays an important role in marketing tourism products and services (Litvin et al., 2018). More recently, with the arrival of electronic media, in the form of user-generated content (UGC), the importance attached to online reviews posted by peer users has risen even more (Zeng and Gerritsen, 2010) creating new possibilities for marketers (Dellarocas, 2003). These reviews, which were often likened to electronic word-of-mouth (eWOM) have revolutionized the travel industry (Vinod, 2017) facilitating independent travel planning (Xiang et al., 2015). We should also mention that eWOM is particularly important in tourism because of the intangible nature of the industry (Martin-Fuentes et al., 2018). Many independent travelers are now able to select their destination and plan their trip without the help of travel agencies, based on advice shared on electronic media by fellow travelers (Shanka et al., 2002). The advantage of online travel-related UGC is that it is easy to understand (Zhang and Sun, 2017) and is more trustworthy than any marketing material posted by providers of tourism services (Albarq, 2014). Moreover, compared to classical WOM, which in time may fade away, eWOM remains posted and can influence the intentions of many more tourists (Yang et al., 2012).

Considering the popularity of travel websites such as TripAdvisor (Cong et al., 2014), we can safely assert that the power of eWOM has multiplied (Schegg et al., 2008) to become the most influential source when making travel-related decisions (Zhang and Sun, 2017). Founded in 2000, TripAdvisor is the largest online network of travelers in the world with operations in 45 countries, 315 million members and more than 500 million reviews. The main appeal of reviews on TripAdvisor is the perceived objectivity; most 
visitors find these reviews to be credible and useful (Cong et al., 2014). The use of reviews on TripAdvisor in tourism research to examine satisfaction is still in its incipient stage (Egresi, 2017; Egresi, 2015; Wu et al., 2014) and very few studies deal with wildlife tourism (Cong et al., 2014; Prakash et al., 2017a, 2017b, 2017c). Cong et al. (2014) content-analyzed tourist reviews on TripAdvisor of the Chengdu Research Base of Giant Panda Breeding in China. They found that tourist motivations, preferences and satisfaction levels varied. Prakash et al. (2017a) examined the major reasons for visitor dissatisfaction in five national parks in Sri Lanka. They found that $75 \%$ of the negative reviews were related to park management and included: overcrowding, too few species of wildlife that can be observed, high entrance fees and lack of quality interpretation services. A similar study at five ex-situ elephant establishments in Asia revealed that most visitors were dissatisfied mainly with the unethical treatment of elephants and with the lack of conservation relevance. Also many visitors expected more interaction with elephants than they were allowed to have (Prakash et al., 2017b). A third study by Prakash et al. (2017c) explored tourist satisfaction/dissatisfaction with the whale watching operation in Mirissa, southern Sri Lanka. They found that the main complaints of tourists were overcrowding with boats and tourists and harassing the whales.

\section{METHODOLOGY}

Reviews published by users on Tripadvisor between 1 November 2013 and 31 June 2017 were compiled for this study. Only reviews in English were considered, which represented approximately 60.6\% of the total reviews. Each review was entered in an excel document and then exported to QDA Miner and coded as case. QDA miner, developed by Provalis Research is a software package used for coding, annotating, retrieving and analyzing qualitative data in textual and photographic forms. Next, we searched for duplicates and all found duplicates were carefully removed. In the end, a total number of 368 cases (amounting to 40,748 words) were analyzed.

Table 1. Code frequency

\begin{tabular}{|c|c|c|c|c|}
\hline Category & Code & Count & \% Codes & \% Cases \\
\hline \multirow{3}{*}{ Experience } & Worth & 200 & 17.9 & 54.3 \\
\cline { 2 - 5 } & Missed & 83 & 7.4 & 22.6 \\
\cline { 2 - 5 } & Disappointing & 63 & 5.6 & 17.1 \\
\hline \multirow{3}{*}{ Time } & Morning & 93 & 8.3 & 25.3 \\
\cline { 2 - 5 } & Afternoon & 38 & 3.4 & 10.3 \\
\hline \multirow{4}{*}{ Activity } & Bumpy ride & 69 & 6.2 & 18.8 \\
\cline { 2 - 5 } & Photo & 12 & 1.1 & 3.3 \\
\cline { 2 - 5 } & Toilet facilities & 12 & 1.1 & 3.3 \\
\cline { 2 - 5 } & Lunch/breakfast & 13 & 1.2 & 3.5 \\
\cline { 2 - 5 } & Crowded & 113 & 10.1 & 30.4 \\
\cline { 2 - 5 } & Driver/guide & 76 & 6.8 & 20.7 \\
\cline { 2 - 5 } & Dusty road & 19 & 1.7 & 5.2 \\
\hline \multirow{3}{*}{ Wildlife } & Abundant & 132 & 11.8 & 35.9 \\
\cline { 2 - 5 } & Diverse & 60 & 5.4 & 16.3 \\
\cline { 2 - 5 } & Elusive & 54 & 4.8 & 14.7 \\
\hline \multirow{2}{*}{ Entry } & Cost & 54 & 4.8 & 14.7 \\
\cline { 2 - 5 } & Line & 29 & 2.6 & 7.9 \\
\hline
\end{tabular}

In order to compile the list of themes and concepts, manual coding was performed. This was deemed necessary because, often, words were misspelled and/or shortened and 
therefore not picked up by the software. Also, while doing a good job in about 70\% of the cases (Schuckert et al., 2015), text analysis software cannot always understand the real meaning of sentences. In the second part, we used another Provalis software, Wordstat, to better understand and visualize the relationships among words and categories.

\section{FINDINGS}

Following the manual coding process, a number of 17 codes resulted which were further grouped into five categories or themes (experience, time, activity, wildlife and entry). We counted a code only once in any case, regardless of how many times it was mentioned. The most frequently used codes can be seen in table 1 .

International tourists' satisfaction with their overall experience in Yala Park

As can be seen in table 1, over half of all those who posted reviews on TripAdvisor were content with their experience in Sri Lanka's national parks and only a little over $17 \%$ expressed dissatisfaction (for the rest - to 100\% - there is no mention of whether they were satisfied or not in their review). Less than a quarter (22.6\%) lamented for missing the main animal attractions, such as the leopard or the sloth bear but many of these still considered their experience to be satisfactory. For example, one reviewer titled his/her review: "Fantastic - saw everything - except a bear $\odot$ " (Case \# 1). Another reviewer, while sorry for not being "lucky enough to spot a leopard", still started his/her account of Yala Park with “What a great place!” (Case \# 17).

\section{Factors determining tourists' satisfaction}

Tourists can choose to buy either a full-day or a half-day safari. Not all reviewers specified in their post the type of ticket they bought, but of those who did, it seems that the majority preferred the half-day option. In total, "morning" was mentioned 93 times (8.3\% of all codes), or in more than a quarter of all cases, while "afternoon" was mentioned 38 times (more than 10\% of all cases". The morning safari was preferred by some reviewers because - they claimed - afternoons were hot and with fewer animals to see (Case \# 21) while in the early mornings many animals come to the waterholes to drink and therefore are easy to spot (Case \# 219). Others, on the other hand, recommended afternoon visits because "The atmosphere in the late afternoon is magical, the sun begins to set and the air becomes cooler. The light is perfect for photographs and the animals leave their shelters, which increases chances of encounters" (Case \# 38). Moreover, there could be "a lot less safari jeeps in the park in the evening to contend with and it made seeing the wildlife a bit easier" (Case \# 52). Further others recognize that, while both could be equally satisfying, morning and afternoon safaris could offer different experiences (Case \# 33).

In the "activity" category, the codes that appeared the most frequently are "crowded" (113 times, 30\% of all cases), "driver/guide" (76 times, almost 21\% of all cases and "bumpy ride" (69 times, almost $13 \%$ of all cases). As we can see, the problem of jeeps crowding the few roads in the park has bothered numerous reviewers (table 2).

As can be understood from the quotes above, the great number of safari jeeps that are allowed to enter the park every day would scare away the animals depriving tourists of animal sights, which is the very reason visitors booked the safari. Moreover, when rushing at full speed to a site where an animal was spotted, jeep drivers endanger the integrity of tourists, especially considering that roads are in very poor state. For this reason, one reviewer stated clearly that the safari was "Not advisable for aged people or people with back pain as most of the drive is bumpy and it will hurt the back" (Case \# 71). Other reviewers also mentioned the constant dust and the pollution generated by the numerous jeeps clustering together. While "crowded", "bumpy ride", and "dusty road" were used 
with negative connotations, the code "driver/guide" was used in both positive and negative situations. For example, one reviewer emphasized that having good guides is paramount to having a satisfying experience in the park: "Our guides, one from the safari company that drove, another from our hotel that served as a spotter/naturalist, were both excellent and saw birds and other animals that we would have missed with our untrained eye" (Case \# 52). Unfortunately, some visitors may end up with "young and inexperienced persons who are really just drivers, who don't really know much about animals and like car-racing all the time" (Case \# 217).

Table 2. Quotes that illustrate overcrowding

\begin{tabular}{|l|c|}
\hline \multicolumn{1}{|c|}{ Quote } & Case \# \\
\hline $\begin{array}{l}\text { [...] Do not come to Yala expecting a Serengeti-like experience, it is not that. You will } \\
\text { see lots of other jeeps especially if seeing some of the larger game the park contains } \\
\text { - Leopards, Elephants, etc. In the case you see these creatures, be ready to see up to } \\
\text { 3o other jeeps that will come rushing to the spot where the animals are. [...] }\end{array}$ & 52 \\
\hline $\begin{array}{l}\text { [...] Go with the company that accesses Yala from the back, not the main entrance. } \\
\text { There are 15o jeeps everyday entering Yala from the main gate and they race with } \\
\text { each other to see animals - absolutely crazy! However there are only } 12 \text { companies } \\
\text { that access from the back gate. [...] }\end{array}$ & \\
\hline $\begin{array}{l}\text { We did a morning safari on } 1 \text { February 2017. We reached the park entrance at about } \\
\text { 5:45am, and got surprised to see so many jeeps. [...] What disappointed us most is } \\
\text { the number of jeeps, which are uncoordinated and disorganized. When drivers got } \\
\text { the info about sighting something interesting, so many of them rush to the place, } \\
\text { creating big traffic jam and noise/air pollution. The Park should seriously consider } \\
\text { limiting the number of jeeps; otherwise, visitors cannot enjoy nature, and nature } \\
\text { will be gradually damaged by jeeps. }\end{array}$ & \\
\hline $\begin{array}{l}\text { I had a good time - really enjoyed it. However, would have been better with less of a } \\
\text { crowd. Every time something is spotted, all the jeeps in the vicinity start to crowd } \\
\text { round, and most often than not, scare the wildlife away. [...] }\end{array}$ & \\
\hline $\begin{array}{l}\text { The worrying factor is the pressure created by so many vehicles. We did come up } \\
\text { against long backlogs of jeeps clogging the grade roads coming in both directions } \\
\text { rendering any form of escape impossible. }\end{array}$ & \\
\end{tabular}

When analyzing the quotes that best illustrate the codes "photo", "bathroom facilities" and "lunch/breakfast" we notice that the tone is generally neutral ("We were here for taking wildlife photo, ideal place when you have good driver/guide. Crowded, especially when leopard was seen (sic!). And many peoples take photo with compacts, mobile and tablets :-) even when 3oomm telephoto lens is short", Case \# 216), although it sometimes could be positive ("The toilet break by the seaside was heavenly with sea breeze to add it on", Case \# 23) or negative ("When we approached the toilet facility near the beach, I saw trash everywhere and used toilet paper (we were advised to actually not use the toilet because it was so unclean). I think that park management should install proper facilities so as to avoid the amount of rubbish in the park", Case \# 226), especially when mentioning toilet/bathroom facilities. We found that three codes could best describe the characteristics of wildlife in the park. Two of these can be considered positive ("abundant" and "diverse") and one negative ("elusive"). Wildlife is characterized as "abundant" in 132 cases (almost $36 \%$ of all cases) and diverse in 60 cases (over 16\%). Only $14.7 \%$ of the reviewers complained for the scarcity of the wildlife in the park (table 3). The last category ("entry") includes two codes that best describe the experience of the reviewers before entering the park ("cost" and "line"). When mentioning the cost of the tickets to enter the park, most reviewers simply reported a figure (often quoted in local 
currency) without making any comment whether they felt it was too high, too low or just right. Out of those who commented, most seemed to believe that tickets were rather expensive. For example, one reviewer lamented: "[...] We paid 4300 per person entry fee and 5000 for a truck with a friendly and good driver/guide. Could be a bit too much! [...]" (Case \# 34). Another visitor considered that the ticket was " a tad bit expensive but worth it" because the reserve is well run (Case \# 30). Yet another tourist even appreciated the entrance fee to be reasonable when traveling in group as discounts can be negotiated (Case \# 228). While the code "cost" is used in both positive and negative contexts, "line" is used exclusively to denote a complaint. For example, one visitor reported: "We had read reviews that the park is commercial and the host at our hotel informed us there are about 100 jeeps!! We thought he's definitely exaggerating! However, we were shocked to see a huge line-up at the entrance of the park. [...]" (Case \# 46).

Table 3. Quotes showing positive and negative views of the wildlife

\begin{tabular}{|c|c|}
\hline $\begin{array}{l}\text { Positive views of the wildlife (under } \\
\text { the codes "abundant" \& "diverse") }\end{array}$ & $\begin{array}{l}\text { Negative views of the wildlife } \\
\text { (under the code "elusive") }\end{array}$ \\
\hline $\begin{array}{l}\text { Having never been on safari before, this was a } \\
\text { wonderful first experience. We saw loads of } \\
\text { different creatures including elephants, } \\
\text { crocodiles, water buffalo, many different } \\
\text { birds and even a black bear! The park has a } \\
\text { wide open plains, numerous lakes, rocky } \\
\text { outcrops and lots of tightly packed bush, so } \\
\text { there's plenty of variation. (Case \# 29) }\end{array}$ & $\begin{array}{l}\text { If sitting on a highway with } 40 \text { other cars is } \\
\text { your kind of thing, this safari is for you. While } \\
\text { novel for the first hour or so, after a while it } \\
\text { becomes a little tiresome. Animals are few and } \\
\text { far between (I can hardly blame them) and } \\
\text { there seemed to be little explanation by any of } \\
\text { the guides for what we were actually } \\
\text { seeing.[...] (Case \# 111) }\end{array}$ \\
\hline $\begin{array}{l}\text { Vast land, scenic trails, abundance of wildlife, } \\
\text { from birds to mammals, we have sighted } \\
\text { leopards, elephants, kingfishers, all kinds of } \\
\text { colorful birds, wild boar, crocodile, } \\
\text { peacocks...a serene park. } \\
\text { However, since this reserve is one of the key } \\
\text { attraction, it tends to be slightly overcrowded } \\
\text { at the entrace. (Case \# 39) }\end{array}$ & $\begin{array}{l}{[\ldots] \text { it was all nothing but a huge }} \\
\text { disappointment. The driver just kept on } \\
\text { driving and we were sitting at the back of the } \\
\text { jeep hoping to see some wildlife. All we saw } \\
\text { was buffaloes, monkeys, rabbit, deer and } \\
\text { crocs. Besides crocs, all of this we have seen } \\
\text { outside Jungle too so we felt like our money } \\
\text { was entirely wasted. The Jungle literally felt } \\
\text { empty! [...] (Case \# 138) }\end{array}$ \\
\hline $\begin{array}{l}\text { Yala National Park was predominantly low } \\
\text { thorny acacia habitat. There was an } \\
\text { abundance of wildlife: deer, crocodiles, wild } \\
\text { boar, elephants, wild buffaloes, monkeys and } \\
\text { a huge variety of water birds.[...](Case \# 103) }\end{array}$ & $\begin{array}{l}\text { Average safari with few animals to see } \\
\text { [...] In all we seen approx } 6 \text { animals and } 4-5 \\
\text { birds, nothing spectacular and not really worth } \\
\text { doing if you previously have been to a good } \\
\text { safari or zoo. (Case \# 198) }\end{array}$ \\
\hline
\end{tabular}

Next we explored the potential relationship among these codes by using the codes co-occurrencies tool available in QDA Miner. Results are displayed in the form of dendograms, concept maps and proximity plots which were obtained through the computation of co-occurrencies index and the application of hierarchical cluster analysis and multidimensional scaling on all codes. For example, based on proximity values calculated on all codes, we obtained a 2D concept map (figure 1).

Each circle represents a code and the circle is proportional with the frequency of the code. The distance between pairs of circles indicates how likely these codes tend to appear together. The thickness of the connecting line is directly proportional to the strength of the link. Figure 1 shows that the code "worth" is very likely to appear together with "abundant" in reference to the wildlife and the link is shown to be very strong. On the other hand, the code "disappointing" is most likely to appear together with "elusive" 
(strong link) and with "crowded" (connected by a somewhat weaker link). To confirm some of our assertions made earlier, we see that "driver-guide" is located approximately equidistant from "worth" and "disappointing". The code "cost", while located closer to "disappointing" than to "worth" is not particularly linked to "disappointing". Another interesting finding is that, while "line" is always used as negative, it is situated at approximately the same distance from "disappointing" and from "worth". This shows that, while definitely a drawback, long lines cannot be blamed for ruining the experience of the park visitors. Similarly, we notice that the code "missed" appears close to "worth" proving what we said earlier that, while some tourists were sorry for missing the iconic animals this did not deter them from enjoying their time in the park.

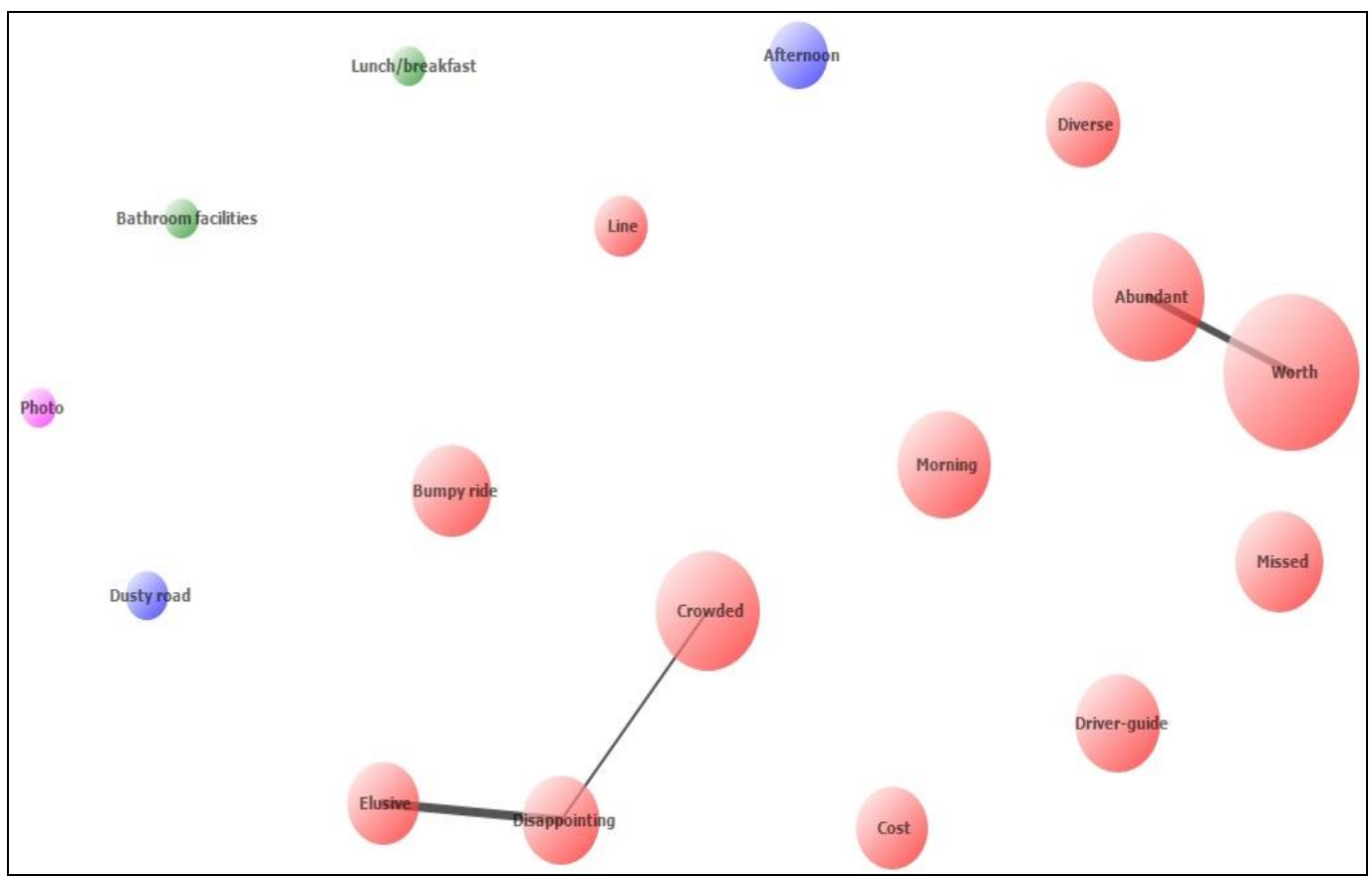

Figure 1. 2D concept map with links

An even better visualization of the connections between codes could be obtained through the link analysis tool using a network graph. This feature allows us to explore relationships among codes and detect underlying patterns and structures of cooccurrencies. Again, the thickness of the lines connecting the nodes denotes the strength of the relationship (figure 2). Based on figure 2, we may conclude that the main factors that have contributed to a "disappointing" experience are (in this order): the scarcity of animals to be observed in the park and the high density of vehicles (all chasing the same, few animals). Bumpy roads and the relatively high cost of the tickets could also determine dissatisfaction, but to a lesser extent. On the other hand, those who assessed their experience as "worthy" were those who were lucky to observe an abundant and diverse fauna (even if, sometimes, missing the iconic animals) and who had the chance of hiring a capable driver/guide. Interestingly, these figures reveal that there is a connection between those who self-assessed their experience as "worthy" and those who took the morning safari (even though this had the disadvantage of long lines at the park entrance). 


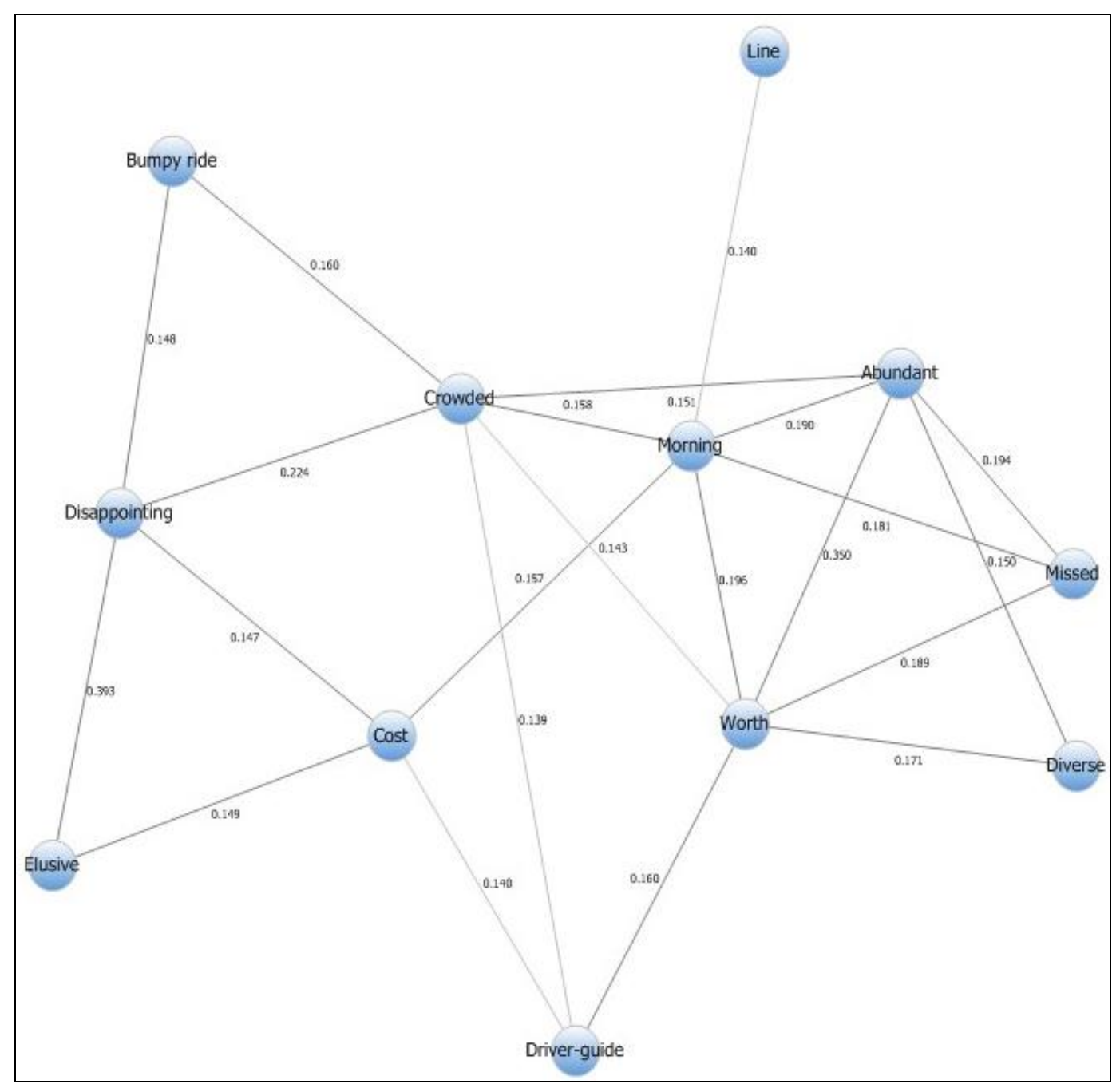

Figure 2. Link analysis

However, the most accurate tool to graphically display the distance between objects is the proximity plot. The proximity plot presents the measured distance from a selected code to all other codes on a single axis. All measured distances are from the 0 point. At o point there is absence of similarity or co-occurrence (figure 3 ).

Figure 3 shows that what matters most in the satisfaction of park visitors is the characteristics of wildlife as a very small percentage of cases include both "elusive" and "worth" codes or the code "disappointing" together with "abundant" and/or "diverse".

\section{DISCUSSION, CONCLUSIONS AND RECOMMENDATIONS}

In this study we attempted to assess satisfaction of foreign visitors with their safari experience in Yala Park, Sri Lanka, based on the reviews posted by them on TripAdvisor, the most popular website for travel advice. We found that the number of satisfied visitors was three times the number of disappointed tourists. 
This is consistent with previous findings by Akama and Kieti (2003), and Okello et al. (2008) showing that between $66 \%$ and $86 \%$ percent of all international tourists visiting national parks in Africa were satisfied with their experience and were willing to return in the future and/or recommend the place to others. However, we agree with Buultjens et al. (2016) that this apparent satisfaction could mask a highly uneven visitor experience which can be only understood from reading the comments made by the visitors rather than from any numerical assessment.

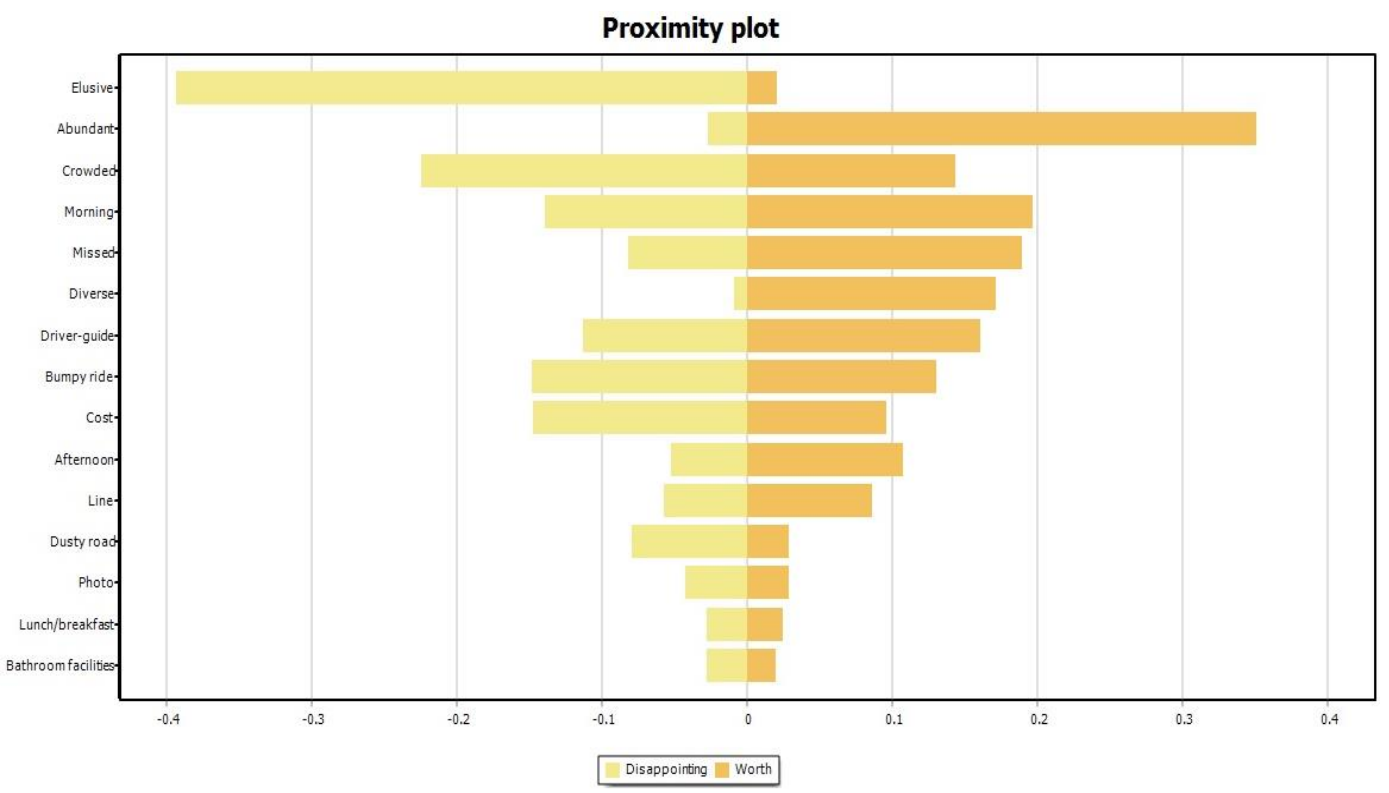

Figure 3. Proximity plot for the "worth"/"disappointing" codes

Further, we found that satisfaction/dissatisfaction of visitors depends on three main factors:

\section{The number and diversity of animals}

Our study has shown very clearly that those visitors who were lucky to spot and observe a great number of different animals during their safari tended to be highly satisfied with their experience while those who complained about the shortage of animals in the park were generally dissatisfied with their experience. Another conclusion that has managerial implications is that, while many tourists choose Yala Park over other parks in Sri Lanka due to its high density and easy visibility of leopards, elephants and sloth bears, for most of these tourists getting to see these animals, while certainly welcomed and appreciated, is not a condition sine-qua-non for a satisfactory experience.

This can be seen from the fact that, while $22 \%$ of the visitors lamented for missing the main animal attractions, only $17 \%$ complained for having a disappointing experience. Moreover, as has been shown in this paper, the main reasons for disappointment had nothing to do with missing the main animal attractions. We agree with Alegre and Garau (2010) that the presence of these animals may generate satisfaction, yet their absence may not necessarily lead to dissatisfaction. This conclusion comes to confirm previous findings of similar research undertaken in African parks. For example, in Amboseli National Park (Kenya) it was found that "the big five" (lion, leopard, elephant, Cape 
buffalo and black and white rhinoceros) were not as important tourist attractions as previously thought (Okello et al., 2008). Another study in KwaZulu Natal, South Africa revealed that less experienced and wealthier visitors may be attracted to the popular animals while more experienced and lower income visitors prefer to see a broader range of species (Di Minin et al., 2013). The conclusion is that tourists are, in general, interested in seeing a variety of wildlife rather than one or a few specific species.

\section{The number of vehicles and visitors}

Our study identified vehicle crowding as one of the main problems causing dissatisfaction among visitors of Yala Park. This finding is by no means surprising. A number of previous studies have also reported overcrowding, and especially crowding of jeeps or motorized vehicles (Behan et al., 2001) as a major problem affecting the social and environmental carrying capacity of wildlife (Buultjens et al., 2005; Prakash et al., 2017c). Yet - and this is, indeed, surprising - in spite of 20 years of research showing the negative impact of crowding on tourist satisfaction, park management has done nothing to alleviate the problem. Drivers keep chasing the representative animals crowding around them and trying to get as close as possible in order to offer their customers the best view. This behavior is based on the belief that tourists want to get close and, if possible, even interact with animals. A number of recent studies seem to support this practice. For example, in a study that examined tourists' satisfaction with observing giant pandas in a Chinese national park, Cong et al. (2014) concluded that tourist satisfaction levels tended to increase with proximity and interaction with the animals. Also, in Australia, the level of interaction between visitor and wildlife is quite high. However, in Australia there are protocols in place for sustainably managing these interactions (Rodger et al., 2007) which is not the case in developing countries like Sri Lanka. Moreover, many tourists, especially from the West are highly aware of the environmental implications and perceive this practice as animal harassment rather than as a means to please tourists (Okello et al., 2008; Prakash et al., 2007c). Indeed, crowding around and in close proximity of animals can cause unnecessary stress to the wildlife (Buultjens et al., 2005; Sindiga and Kamunah, 1999) and diminishes the visitors' experience in the park (Buultjens et al., 2005; Rathnayake 2016b; 2015).

It is not only crowding and proximity that threaten animal welfare but also noise pollution (Buultjens et al., 2005; Rathnayake, 2015). The noise generated by the numerous vehicles congregating in close proximity of the animals as well as the behavior of some tourists could lead to behavioral changes of animals (Ranaveerage et al., 2015). Indeed, previous studies have shown that concentration of more than six vehicles greatly reduces the chances of an animal to hunt and inhibits mating which is important for the survival of the species (Okello et al., 2008). Another study in a protected area in Sri Lanka that examined the feeding activity of elephants in the presence versus in the absence of tourists found that feeding of elephants was significantly affected by the presence of tourists in the proximity. It was also found that elephants were disturbed by the noise made by the vehicles which came very close to the animals, by the behavior of tourists and by the time of the tours (Ranaweerage et al., 2015).

\section{Knowledge and skills of drivers and guides}

One of the main reasons tourists go on wildlife safaris is to learn more about wildlife and their habitat. A good guide can help tourists better identify wildlife and learn more about wildlife behavior (Moscardo et al., 2004). A strong educational component to wildlife safaris can enhance visitor experience (Moscardo et al., 2004) and can significantly influence their biodiversity conservation attitudes (Apps et al., 2017). Our study also concluded that one of the major factors influencing satisfaction of 
park visitors is the skillfulness and knowledge of safari guides and drivers. Those tourists who were lucky to be guided by knowledgeable individuals ended up being satisfied with their safari experience while many of those who had been assigned to inexperienced and/or unprepared guides wrote about an unsatisfactory experience.

Thus, our findings confirm previous conclusions that service quality has a significant positive relationship with tourist satisfaction (Chen et al., 2011) and that the tour guides can have a significant impact on tourist satisfaction (Huang et al., 2015). The main problem is that in Sri Lanka many guides are uneducated and untrained, with little knowledge of English or other foreign languages. Besides this, Buultjens et al. (2005) offer another explanation for the guides not communicating more with the visitors.

They argue that in a hierarchical society like the one in Sri Lanka it is difficult for guides coming from the country's lower class to guide middle and upper class local and international tourists. Similar to other studies (Okello et al., 2008), our research also revealed that tourists do not like the practice by drivers and tour guides of rushing from one animal to another and focusing on few species which guides assumed tourists want to see rather than spending more time watching animals.

In order to correct the shortcomings highlighted in this study and to ensure a more sustainable wildlife tourism operation in Yala Park, we recommend park management to:

1. Understand that animals are the main attraction of the park. Most tourists choose to visit Yala National Park for its abundance and diversity of wildlife. Due to being such a precious resource, resident animals should be treated with respect. In order to manage wildlife in a sustainable way, jeep drivers and guides should not be allowed to harass animals. Not only that this practice harms the animals but also most tourists disagree with it.

2. Understand that, while being able to spot a leopard could mean the apex of a safari, this is not the main reason most tourists visit the park for. Most tourists understand that the park is not a zoo; thus, viewing certain animals is not guaranteed. For most tourists, not being able to see a leopard will not make them dissatisfied with the tour. Drivers and guides should, therefore, stop chasing the so-called representative animals and instead try and show a diversity of species.

3. Ask tour leaders to slow down. They should organize their tour in a way to spend more time viewing wildlife than racing from one spot to another.

4. Reduce the number of tourists and vehicles allowed into the park. In order to ensure sustainability of a wildlife tourism operation not only animal management is important but also people management (Rodger and Moore, 2014). One major problem our study has identified regarding sustainability of the tourism operation in Yala National Park is overcrowding with tourists and motorized vehicles. In that the situation here is similar to other places in Sri Lanka that are popular with wildlife tourists and is a result of poor regulation that does not offer any control over the number of vehicles admitted (Buultjens et al., 2016). We agree with Ranaveerage et al. (2015) that, in order to maintain sustainability of tourism in protected areas, the number of tourists and the behavior of jeep drivers and guides should be controlled. This could be achieved by implementing a sustainable quota system (Buultjens et al., 2005) or, as Rathnayake (2016a) recommends, by introducing a pricing policy for observing animals in the parks.

5. In order to increase tourists' satisfaction, tour guides should be better educated and better trained in how to deal with tourists' needs (see also Reynolds and Braithwaite, 2001). Previous research has also shown that high levels of satisfaction were associated with tourist involvement in tour decision making regarding where to stop and what animals to watch (Okello et al., 2008). 
What Makes Wildlife Tourists Happy and what Disappoints

Them? Learning from Reviews Posted on Tripadvisor

\section{REFERENCES}

Akama, J.S. \& Kieti, D.M. (2003). Measuring tourist satisfaction with Kenya's wildlife safari: A case study of Tsavo West National Park. Tourism Management, 24, 73-81.

Akama, J.S., Maingi, S. \& Camargo, B.A. (2011). Wildlife conservation, safari tourism and the role of tourism certification in Kenya: A postcolonial critique. Tourism Recreation Research, 36(3), 281-291.

Albarq, A.N. (2014). Measuring the impacts of online word-of-mouth on tourists' attitude and intentions to visit Jordan: An empirical study. International Business Research, 71(1), 14-22.

Alegre, J. \& Garau, J. (2010). Tourist satisfaction and dissatisfaction.Annals of Tourism Research, 37(1), 52-73.

Alen Gonzalez, M.E., Rodriguez Comesana, L. \& Fraiz Brea, J.A. (2007). Assessing tourist behavioral intentions through perceived service quality and customer satisfaction.Journal of Business Research, 60, 153-160.

Andriotis, K., Agiomirgianakis, G., \& Mihiotis, A. (2008). Measuring tourist satisfaction: A factor-cluster segmentation approach.Journal of Vacation Marketing, 14(3), 221-235.

Apps, K., Dimmock, K, Lloyd, D.J. \& Huveneers, C. (2017). Is there a place for education and interpretation in shark-based tourism? Tourism Recreation Research, 42(3), 327-343.

Ballantyne, R., Packer, J. \& Falk, J. (2011). Visitors' learning for environmental sustainability: testing short- and long-term impacts of wildlife tourism experiences using structural equation modeling. Tourism Management, 32(6), 1243-1252.

Behan, J.R., Richards, M.T. \& Lee, M.E. (2001). Effects of tour jeeps in wildland setting on non-motorized recreationists benefits. Journal of Park and Recreation Administration, 19(2): 1-19.

Brooks, S., Spierenburg, M., van Brakel, L., Kolk, A., \& Lukhozi, K.B. (2011). Creating a commodified wilderness: Tourism, private game farming and "third-nature" landscape in Kwazulu-Natal. TijdschriftuoorEconomische en SocialeGeografie, 102(3), 260-274.

Buultjens, J., Ratnayake, I, \& Gnanapala, A. (2016). Whale watching in Sri Lanka: Perceptions of sustainability. Tourism Management Perspectives, 18, 125-133.

Buultjens, J., Ratnayake, I., Gnanapala, A. \& Aslam, M. (2005). Tourism and its implications for management in Ruhuna National Park (Yala), Sri Lanka. Tourism Management, 26, 733-742.

Chandralal, K.P.L. (2010). Impacts of tourism and community attitude towards tourism: A case study in Sri Lanka. South Asian Journal of Tourism and Heritage, 3(2), 41-49.

Chen, C.M., Lee, H.T., Chen, S.H. \& Huang, T.H. (2011).Tourist behavioral intentions in relation to service quality and customer satisfaction in Kinmen National Park, Taiwan.International Journal of Tourism Research, 13, 416-432.

Cong, L., Wu, B., Morrison, A.M., Shu, H. \& Wang, M. (2014). Analysis of wildlife tourism experiences with endangered species: An exploratory study of encounters with giant pandas in Chengdu, China. Tourism Management, 40, 300-310.

Dellarocas, C. (2003). The digitization of word-of-mouth: Promise and challenges of online feedback mechanisms. Management Science, 49(10), 1407-1424.

Deng, J., King, B. \& Bauer, T. (2002). Evaluating natural attractions for tourism. Annals of Tourism Research, 29(2), 422-438.

Di Minin, E., Fraser, I., Slotow, R. \& MacMillan, D.C. (2013). Understanding heterogeneous preference of tourists for big game species: Implications for conservation and management. Animal Conservation, 16, 249-258.

Dmitrovic, T., Kenezevic Cvelbar, L., Kolar, T., Makovec Brencic, M., Ogranjensek, I. \& Zabkar, B. (2009).Conceptualizing tourist satisfaction at the destination level.International Journal of Culture, Tourism and Hospitality Research, 3(2), 116-126.

Duffy, R. \& Moore, L. (2010). Neoliberalizing nature? Elephant-back tourism in Thailand and Botswana.Antipode, 42(3), 738-762.

Egresi, I. (2017). Tourists' satisfaction with shopping experience based on reviews on Trip Advisor. Tourism: An Interdisciplinary Journal, 65(3), 330-345.

Egresi, I. (2016). Alternative tourism: Definition and characteristics. In I. Egresi (Ed.), Alternative Tourism in Turkey: Role, Potential Development and Sustainability (pp. 57-69). Cham, Switzerland: Springer International.

Egresi, I. (2015). Tourists' shopping satisfaction in Istanbul's traditional markets. In Proceedings of the Geobalcanica International Scientific Conference, Skopje, Macedonia, June 5-7 (pp. 292-298).

Egresi, I. \& Polat, D. (2016). Assessing tourists' satisfaction with their shopping experience in Istanbul. GeoJournal of Tourism and Geosites, 9(2), 172-186.

Higginbottom, K. (2004). Wildlife tourism: An introduction. In K. Higginbottom (Ed.), Wildlife Tourism: Impacts, Management and Planning (pp. 1-14). Altona, Vic, Australia: Common Ground Publishing.

Huang, S., Weiler, B. \& Assaker, G. (2015). Effects of interpretative guiding outcomes on tourist satisfaction and behavioral intention. Journal of Travel Research, 54(3), 344-358. 
International Water Management Institute (2006). Ruhuna National Park. Sri Lanka Wetlands Information and Database. https://web.archive.org/web/20110726201837/http://dw.iwmi.org/wetlandprofile/Ruhuna.asp (accessed June 27, 2018).

Kittle, A. (2009). Tracking the Lankan leopard.The Sunday Times, May 10. http://www.sundaytimes.lk/o90510/Plus/sundaytimesplus_12.html. (accessed June 27, 2018).

Lee, C.-K., Yoon, Y.-S. \& Lee, S.-K. (2007). Investigating the relationships among perceived value, satisfaction and recommendations: The Case of Korean DMZ. Tourism Management, 28(1), 204-214.

Litvin, S.W., Goldsmith, R.E. \& Pan, B. (2018). A retrospective view of electronic word-of-mouth in hospitality and tourism management. International Journal of Contemporary Hospitality Management, 30(1), 313-325.

Martin-Fuentes, E., Mateu, C. \& Fernandez, C. (2018). Does verifying users influence rankings? Analyzing Booking.com and TripAdvisor. Tourism Analysis, 23(1), 1-15.

Mbaiwa, J.E. (2011). Changes on traditional livelihood activities and lifestyles caused by tourism development in the Okavango Delta, Botswana. Tourism Management, 32(5), 1050-1060.

Mittermeier, R., Myers, N., Mittermeier, C. \& Robles, G. (1999). Hotspots: Earth's Biologically Richest and Most Endangered Terrestrial Ecoregions. Mexico City, Mexico: CEMEX SA.

Moscardo, G., Woods, B., \& Saltzer, R. (2004). The role of interpretation in wildlife tourism. In K. Higginbottom (Ed.), Wildlife Tourism: Impacts, Management and Planning (pp. 231-251). Altona: Common Ground.

Newsome, D., Dowling, R.K. \& Moore, S.A. (2004). Wildlife Tourism.Clevedon, UK: Channel View.

Niven, C., Noble, J., Forsyth, S., \& Wheeler, T. (1999). Sri Lanka: Cool Coasts, High Teas, Hot Curries (7th Edition). Lonely Planet.

O'Connor, P. (2008). User-generated content and travel: A case study on tripadvisor.com. In P. O'Connor, W. Hopken and U. Gretzel (Eds.), Information and Communication Technologies in Tourism (pp. 44-58). Vienna, Austria: Springer.

Oh, C.-O.H. (2001). Revisiting importance-performance analysis.Tourism Management, 22(6), 617-627.

Okello, M.M., D’Amour, D.E. \& Manka, S.G. (2008). Tourism attractions and satisfaction of Amboseli National Park.Tourism Analysis, 13, 373-386.

Okello, M.M., Wishitemi, B.E.L., \& Lagat, B. (2005). Tourism potential and achievement of protected areas in Kenya: Criteria and prioritization. Tourism Analysis, 10(2), 151-164.

Oliver, R. (1980). A cognitive model of the antecedents and consequents of satisfaction decisions. Journal of Marketing Research, 17(4), 460-469.

Pizam, A. \& Milman, A. (1993). Predicting satisfaction among first time visitors to a destination by using the expectancy disconfirmation theory. International Journal of Hospitality Management, 12(2), 197-209.

Pizam, A., Neumann, Y. \& Reichel, A. (1978). Dimensions of tourism satisfaction with a destination area. Annals of Tourism Research, 5, 314-322.

Prakash, T.G.S.L., Perera, P.K.P., Newsome, D. \& Kusuminda, T.G.T. (2017a). Reasons for visitors' dissatisfaction in national parks based tourism in Sri Lanka. Proceeding of Annual Session of Department of Wildlife Conservation, 15-16 August, Colombo, Sri Lanka.

Prakash, T.G.S.L., Perera, P.K.P., Perera, A.G.K.C. \& Fernando, P. (2017b). Visitor discontent at five ex-situ elephant conservation establishments in Asia.Gajah, 47, 24-29.

Prakash, T.G.S.L., Perera, P.K.P. \& Amarasinghe, N.S. (2017c). The visitor perceptions on whale-watching tours based on Mirissa, Sri Lanka. 22 $2^{\text {nd }}$ International Forestry and Environment Symposium, Waduwa, Sri Lanka.

Ranaveerage, E., Ranjeewa, A.D.G. \& Sugimoto, K. (2015). Tourism-induced disturbance of wildlife in protected areas: A case study of free ranging elephants in Sri Lanka. Global Ecology and Conservation, 4, 625-631.

Rathnayake, R.M.W. (2016a). Pricing the enjoyment of "elephant watching" at the Mineriya National Park in Sri Lanka: An analysis using CVM. Tourism Management Perspectives, 18, 26-33.

Rathnayake, R.M.W. (2016b). Vehicle crowding vs. consumer surplus: A case study at Wasgomuwa National Park in Sri Lanka applying HTCM approach. Tourism Management Perspectives, 20, 30-37.

Rathnayake, R.M.W. (2015). How does "crowding" affect visitor satisfaction at the Horton Plains National Park in Sri Lanka? Tourism Management Perspectives, 16: 129-138.

Reynolds, P.C. \& Braithwaite, D. (2001).Towards a conceptual framework for wildlife tourism.Tourism Management, 22(1), 31-42.

Rodger, K. \& Moore, S.A. (2004). Bringing science to wildlife tourism: The influence of managers and scientists' perceptions. Journal of Ecotourism, 3(1), 1-19.

Rodger, K., Moore, S.A. \& Newsome, D. (2007). Wildlife tours in Australia: Characteristics, the place of science and sustainable futures. Journal of Sustainable Tourism, 15(2), 160-179.

Schegg, R., Liebrich, A., Scaglione, M. \& Ahmad, S. (2008). An exploratory field study of Web 2.o in tourism. In P. O'Connor, W. Hopken and U. Gretzel (Eds.), Information and Communication Technologies in Tourism (pp. 152-163). Vienna, Austria: Springer. 
Schuckert, M, Liu, X., \& Law, R. (2016). Insights into suspicious online ratings: Direct evidence from TripAdvisor. Asia Pacific Journal of Tourism Research, 21(3), 259-272.

Schuckert, M, Liu, X., \& Law, R. (2015). Hospitality and tourism online reviews: Recent trends and future directions. Journal of Travel and Tourism Marketing, 32, 608-621.

Senaratna, P.M. (2009). Yala (in Sinhala). In Sri LankaweJathika Vanodhyana (National Parks of Sri Lanka) (2 ${ }^{\text {nd }}$ Edition). Nugegoda, Sri Lanka: Sarasawi Publishers, pp. 22-69.

Shanka, T., Ali-Knight, J. \& Pope, J. (2002). Intrastate travel experiences of international students and their perceptions of Western Australia as a tourist destination. Tourism and Hospitality Research, 3(3), 245-256.

Sindiga, I. \& Kamunah, M. (1999).Unplanned tourism development in Sub-Saharan Africa with special reference to Kenya. Journal of Tourism Studies, 10(1), 25-37.

Som, A.P.M. \& Badarneh, M.B. (2011). Tourist satisfaction and repeat visitation: Toward a new comprehensive model. World Academy of Science, Engineering and Technology, 50, 1106-1113.

Tisdell, C. \& Wilson, C. (2001). Wildlife-based tourism and increased support for nature conservation financially or otherwise. Tourism Economics, 7, 233-249.

Torres-Sovero, C., Gonzalez, J.A., Martin-Lopez, B. \& Kirkby, C.A. (2012). Socio-ecological factors influencing tourist satisfaction in three ecotourism lodges in the southeastern Peruvian Amazon. Tourism Management, 33(3), 545-552.

Valentine, P. \& Birtles, A. (2004). Wildlife watching. In K. Higginbottom (Ed.), Wildlife Tourism: Impacts, Management and Planning (pp. 15-34). Altona, Vic, Australia: Common Ground Publishing.

Vinod, B. (2011). The future of online travel. Journal of Revenue and Pricing Management, 10, 56-61.

Weerakoon, D. (2012). A brief overview of the biodiversity of Sri Lanka. In D.K. Weerakoon and S. Wijesundar (Eds.), The National Red List 2012 of Sri Lanka: Conservation Status of Fauna and Flora (pp. xviixix). Colombo, Sri Lanka: Ministry of Environment.

Wu, M-Y., Wall, G. \& Pearce, P. (2014). Shopping experiences: International tourists in Beijing's Silk Market. Tourism Management, 41, 96-106.

Xiang, Z., Magnini, V.P. \& Fesenmeier, D.R. (2015). Information technology and consumer behavior in travel and tourism: Insights from travel planning using the internet. Journal of Retailing and Consumer Services, 22, 244-249.

Yang, J., Mai, E. \& Ben-Ur, J. (2012). Did you tell me the truth? The influence of online community on eWOM. International Journal of Market Research, 64, 369-389.

Yoon, Y. \& Uysal, M. (2005). An examination of the effects of motivation and satisfaction on destination loyalty: A structural model. Tourism Management, 26, 45-56.

Yu, L. \& Goulden, M. (2006). A comparative analysis of international tourists' satisfaction in Mongolia. Tourism Management, 27(6), 1331-1342.

Zeng, B. \& Gerritsen, R. (2014). What do we know about social media in tourism? A review.Tourism Management Perspectives, 10, 27-36.

Zhang, L. \& Sun, X. (2017). Can travel information websites do better? Facilitating the decision-making experience for tourists. In S. Yamamoto (Ed.), Human Interface and Management of Information: Supporting Learning Decision Making and Collaboration (pp. 302-311). Cham, Switzerland: Springer International.

Submitted:

02.12 .2018
Revised:

28.01.2019
Accepted and published online 30.01.2019 